\title{
ASSESSMENT OF THE PROFESSIONAL RISK OF EXPOSURE TO COVID-19: A TRANSCULTURAL ADAPTATION
}

\author{
Herica Silva Dutra' ${ }^{1}$ \\ Maira Buss Thofehrn² (1) \\ Lidiane Silva Dutra ${ }^{3}$ (D) \\ Camila Ribeiro Araújo ${ }^{1}$ (D) \\ Luciene Muniz Braga ${ }^{4}$ (C) \\ Fábio da Costa Carbogim ${ }^{1}$ (]) \\ Angélica da Conceição Oliveira Coelho ${ }^{1}$
}

${ }^{1}$ Universidade Federal de Juiz de Fora, Programa de Pós-graduação em Enfermagem. Juiz de Fora, Minas Gerais, Brasil. ${ }^{2}$ Universidade Federal de Pelotas, Programa de Pós-graduação em Enfermagem. Pelotas, Rio Grande do Sul, Brasil. ${ }^{3}$ Secretaria Estadual de Saúde de Minas Gerais. Juiz de Fora, Minas Gerais, Brasil. ${ }^{4}$ Universidade Federal de Viçosa, Programa de Pós-graduação em Ciências da Saúde. Viçosa, Minas Gerais, Brasil.

\begin{abstract}
Objective: to translate and transculturally adapt the Risk assessment and management of exposure of health care workers in the context of COVID-19 questionnaire.

Method: this is a methodological study. The translation, back-translation, synthesis, evaluation by experts committee and pre-test stages were followed. The participants were invited by electronic means and answered an online questionnaire. The data were collected between June and September 2020. Content validation by the experts committee was verified using the Content Validity Index. The pre-test participants assessed the instrument's applicability by means of the "Assessment of Instruments' Feasibility" questionnaire.

Results: the study participants were four translators, eight evaluators in the experts committee and 35 professionals who answered the pre-test. The changes suggested by the experts committee were accepted and consensus was reached in two evaluation rounds, obtaining a content validity index higher than 0.80 for all items of the instrument. The pre-test version presented good applicability and satisfactory reliability $(0.76)$. Conclusion: the instrument was adapted for use in Brazil, which will allow international comparison of the results and using the data obtained for assessment and decision-making in relation to workers' health. In addition to that, its use may be expanded to assess other situations of health professionals' exposure to the risk of contamination by infectious agents.
\end{abstract}

DESCRIPTORS: Validation studies. Occupational risks. Personal protective equipment. Worker's health. Risk management. 


\section{AVALIAÇÃO DO RISCO DE EXPOSIÇÃO PROFISSIONAL AO COVID-19: ADAPTAÇÃO TRANSCULTURAL}

\section{RESUMO}

Objetivo: realizar a tradução e a adaptação transcultural do Risk assessment and management of exposure of healthcare workers in the context of COVID-19.

Método: trata-se de estudo metodológico. Foram seguidas as etapas de tradução, retrotradução, síntese, avaliação por comitê de juízes e pré-teste. Os participantes foram convidados por meio eletrônico e responderam um formulário on-line. Os dados foram coletados entre junho e setembro de 2020. A validação de conteúdo pelo comitê de juízes foi verificada por meio do índice de validade de conteúdo. Os participantes do pré-teste avaliaram a aplicabilidade do instrumento por meio do questionário "Avaliação da Praticabilidade de Instrumentos".

Resultados: participaram do estudo quatro tradutores, oito avaliadores no comitê de juízes e 35 profissionais responderam ao pré-teste. As modificações sugeridas pelo comitê de juízes foram acatadas e o consenso atingido em duas avaliações, obtendo índice de validade de conteúdo superior a 0,80 para todos os itens do instrumento. A versão pré-teste apresentou boa aplicabilidade e confiabilidade satisfatória $(0,76)$.

Conclusão: o instrumento foi adaptado para uso no Brasil, o que permitirá a comparação internacional dos resultados e o uso dos dados obtidos para a avaliação e tomada de decisão em relação à saúde do trabalhador. Além disso, seu uso poderá ser ampliado para avaliar outras situações de exposição de profissionais de saúde ao risco de contaminação por agentes infecciosos.

DESCRITORES: Estudos de validação. Riscos ocupacionais. Equipamento de proteção individual. Saúde do trabalhador. Gestão de riscos.

\section{EVALUACIÓN DEL RIESGO DE EXPOSICIÓN PROFESIONAL AL COVID-19: ADAPTACIÓN TRANSCULTURAL}

\section{RESUMEN}

Objetivo: realizar la traducción y adaptación transcultural del instrumento Risk assessment and management of exposure of healthcare workers in the context of COVID-19.

Método: estudio metodológico en el que se desarrollaron las siguientes etapas: traducción, retrotraducción, síntesis, evaluación a cargo de un comité de expertos y prueba previa (pre-test). Se invitó a los participantes a través de medios electrónicos para que respondieran un formulario en línea. Los datos se recolectaron entre junio y septiembre de 2020. La validación del contenido a cargo del comité de expertos se verificó por medio del Índice de Validez del Contenido. Los participantes de la prueba previa evaluaron la aplicabilidad del instrumento por medio del cuestionario "Evaluación de la Viabilidad de Instrumentos".

Resultados: los participantes del estudio fueron cuatro traductores, ocho evaluadores en el comité de expertos y 35 profesionales que respondieron la prueba previa. Las modificaciones sugeridas por el comité de expertos fueron acatadas y se llegó a un consenso en dos evaluaciones, obteniéndose un Índice de Validez del Contenido superior a 0,80 para todos los ítems del instrumento. La versión de la prueba previa presentó buena aplicabilidad y confiabilidad satisfactoria $(0,76)$.

Conclusión: el instrumento fue adaptado para su uso en Brasil, lo que permitirá realizar una comparación internacional de los resultados y emplear los datos obtenidos con fines de evaluación y toma de decisiones en relación con la salud de los trabajadores. Además, se podrá expandir su utilización para evaluar otras situaciones de exposición de profesionales de la salud al riesgo de contaminación a raíz de agentes infecciosos.

DESCRIPTORES: Estudios de validación. Riesgos ocupacionales. Equipos de Protección Personal. Salud de los trabajadores. Administración de riesgos. 


\section{INTRODUCTION}

COVID-19 is a highly transmissible disease caused by the SARS-CoV-2 pathogen, also known as coronavirus ${ }^{1}$. This disease originated in Wuhan, China, in December $2019^{2}$ and, as of February $23^{\text {rd }}, 2021$, it has affected more than 111 million people around the world, causing more than 2.4 million deaths ${ }^{3}$. Up to the same date, Brazil had already recorded more than 10 million COVID-19 cases and over 247,000 death $^{4}$. Currently, Brazil ranks alarmingly third in the list of countries with the most cases in the world ${ }^{3}$.

Coronavirus is transmitted from one person to another through contact or exposure to droplets or aerosols present in coughing and sneezing between an infected individual and a healthy person. SARS-CoV-2 has already been identified in other body secretions such as feces, urine, saliva and tears, although there is no evidence of transmission via those routes ${ }^{2}$. There is also risk of exposure to the virus through contact with contaminated surfaces ${ }^{5-7}$. One of the complicating factors in identifying the transmission risk lies in the asymptomatic cases because, even without presenting symptoms, infected individuals can transmit the disease ${ }^{5-8}$.

The symptoms can include fever, coughing, fatigue, muscle pain, confusion, headache, sore throat, runny nose, chest pain, diarrhea, nausea and vomiting. Evolution of the disease variably results in an acute respiratory syndrome that can complicate the condition of the infected individual and even lead to death ${ }^{5}$. Older adults and people with previous comorbidities or low immunity present more chances of developing severe complications ${ }^{2}$.

On March $11^{\text {th }}, 2020$, it was declared a pandemic by the World Health Organization (WHO). Given this scenario, the effective and efficient performance of health professionals provides adequate assistance to the individuals affected, as well as it encourages and directs measures to prevent the disease and promote health. Thus, health professionals represent the first line in the response to the coronavirus and, consequently, they are directly exposed to infection risk.

The use of Personal Protective Equipment (PPE) and compliance with consolidated protective measures were reviewed and reinforced to face COVID-19. They include the use of standard precautions for the care of all cases and additional measures for the care of suspected or confirmed cases, observing the precautions regarding contact, droplets or aerosols, according to the type of risk $^{6,9}$. Despite knowing the infection prevention measures, health professionals can experience long working hours, emotional stress, fatigue, burnout, discrimination and physical and psychological violence ${ }^{10}$, which can exert an impact on adherence to the prevention measures.

Thus, it is important to know the health professionals' risk of exposure in the care of suspected or confirmed COVID-19 cases, in order to guide actions aimed at prevention and control of the infection and to assess adherence to the recommendations provided by the health agencies. To this end, the WHO proposed a questionnaire to assess the health professionals' exposure risk and to identify breaches to the preventive measure ${ }^{11}$. This assessment may contribute to the definition of policies capable of reducing health professionals' exposure.

The questionnaire is intended for professionals exposed to patients with confirmed COVID-19 diagnoses; however, due to the limitation in mass testing, it is understood that its use can be extended to workers who also face suspected cases. The instrument aims at: categorizing the risk of each health professional after exposure to a patient with COVID-19 and informing the management about the health professionals exposed based on risk ${ }^{11}$.

Considering that the questionnaire was developed and published in the English language, its use in another language and culture requires a transcultural adaptation study. Thus, the objective of this research was to translate and cross-culturally adapt the Risk assessment and management of exposure of health care workers in the context of COVID-19: Interim guidance instrument to Brazilian Portuguese. 


\section{METHOD}

This is a methodological study for the translation and transcultural adaptation of a measuring instrument. The instrument called Risk assessment and management of exposure of health care workers in the context of COVID-19: Interim guidance was presented by the WHO as a proposal to assess the health professionals' risks of exposure to COVID-1910. According to the WHO publishing license (https://apps.who.int/iris/handle/10665/331496), it is allowed to distribute and adapt the material as long as the source is cited, its use is non-commercial and the same license is maintained (CC BY-NC-SA 3.0 IGO https://creativecommons.org/licenses/by-nc/3.0/igo/).

The instrument is divided in two parts. Part 1: Categorization of the risk of exposure to patients with COVID-19; and Part 2: Management of health workers exposed. The questions for the professionals to answer are in Part 1 and are organized into seven topics: 1) Interviewer information (5 questions); 2) Health worker information (9 questions); 3) Health worker interactions with COVID-19 patient information (6 questions); 4) HCW activities performed on COVID-19 patient in health care facility (5 questions); 5) Adherence to IPC procedures during health care interactions (7 questions); 6) Adherence to IPC measures when performing aerosol-generating procedures (6 questions); and 7) Accidents with biological material (1 question). It is worth noting that some questions are subdivided in order to refine the information obtained from the professional $(3 \mathrm{~F}, 4 \mathrm{C}, 5 \mathrm{~A}, 6 \mathrm{~A} \text { and } 7 \mathrm{~A})^{11}$.

The activities developed with the patients with COVID-19 are assessed with three answer options: yes, no, and does not know. Adherence to the infection control procedures during care and during aerosol-generating procedures is assessed by means of a four-point Likert scale, including the following answer options: "always, as recommended", "most of the time", "occasionally" and "rarely".

In the original version of the document, there is no scoring proposal for the items or score. The assessment of the exposure risk considers community or professional exposure. It is considered community exposure to COVID-19 when the answer "yes" is selected for questions 1D and/or 1E (staying in an environment with and/or traveling close to a confirmed COVID-19 patient). Professional exposure is characterized when the "yes" option is selected for any of questions 4A to 4D in the topic that assesses the activities developed by the health professional with patients with COVID-19.

The classification of the exposure risk is divided into high and low risk. It is considered high risk when the professional did not answer "always, as recommended" to the questions that assess adherence to the infection control procedures during care interactions (questions $5 A$ to $5 G$ ), during aerosol-generating procedures (6A to $6 \mathrm{~F}$ ) and accidents with biological material $(7 \mathrm{~A})$.

To carry out the cross-cultural adaptation process, a method was adopted that includes the following stages: translation; synthesis; back-translation; review by an experts committee; and pretest $^{12}$. The first stage consists in translating the instrument from English to Brazilian Portuguese. For such purpose, two bilingual translators (Portuguese-English) having Portuguese as their mother tongue (Brazilian natives) made their respective translations independently. The translations obtained were then consolidated by an experts committee comprised by two researchers with PhD degrees and previous experience in validation studies, obtaining a synthesis version of the translation.

The synthesis version was translated to the original language (back-translation) by another two bilingual translators (English-Portuguese), whose mother tongue was English. Two independent back-translations were obtained in order to evaluate the presence of discrepancies in meaning and content between the original version and the final translated version.

The study participants were four translators, with a mean age of 39.45 years old and a mean time of professional experience in translation of 15.23 years. As for professional training, two translators had a degree in Letters, one had a specialization in the translation area and one had a master's degree. 
The synthesis version was then submitted to equivalence assessments by an experts committee consisting of eight members. The experts committee was made up by a convenience sample. Professionals with expertise in research methodology, instrument validation and health care were invited, comprising the sample of eight evaluators, most of them female $(75.0 \%)$. Their training varied between master's degrees (12.5\%), PhDs (75.0\%) and post-PhDs (12.5\%). Their prevailing professional activity was teaching (87.5\%), followed by assistance $(12.5 \%)$. The mean age of the participants was 33.63 years old and their mean time of professional experience was 11.75 years.

In this stage, the specialists were asked to evaluate the instrument's adequacy regarding semantic (word meaning, considering vocabulary and grammar), idiomatic (words or expressions that must be equivalent in both languages), cultural (situations or activities experienced in the Brazilian culture) and conceptual (words with different concepts in the two cultures) equivalences between the original and adapted versions ${ }^{13-16}$. The committee members were presented with the translations, the synthesis and the two back-translations, in an instrument created by the researchers to facilitate evaluation of the versions and decision-making.

The assessment was conducted by means of a four-point Likert scale, as follows: $1=$ nonequivalent item; 2 = the item needs major review to evaluate equivalence; 3 = equivalent item, it needs minor changes; and $4=$ absolutely equivalent item. There was a space for suggestions and comments after assessing each item. The Content Validity Index (CVI) was calculated adding up the number of 3 and 4 answers given by the evaluators and dividing that result by the total number of evaluators. The minimum value to obtain acceptable agreement was 0.80 and, ideally, it should be equal to or greater than $0.90^{13-16}$.

Each evaluator assessed the instrument independently. Consolidation of the initial evaluation led to the agreement rate among the evaluators, with which content validity was carried out quantitatively ${ }^{13-16}$. The items whose CVI values did not reach 0.90 were reviewed by the research team and submitted to a new evaluation round.

The version approved by the experts committee was used in the pre-test stage ${ }^{12}$. Application of the questionnaire in this stage involved 35 health professionals who worked in direct care to patients with COVID-19 (suspected or confirmed cases) ${ }^{12}$. In this stage, the questionnaire was applied to 35 health professionals acting in the first line of care to suspected or confirmed COVID-19 patients. The sample was selected for convenience. Most of the pre-test participants were women $(n=28 ; 80.0 \%)$ and lived in different Brazilian regions, as follows: North $(n=3 ; 8.6 \%)$, Northeast $(n=2 ; 5.7 \%)$, Southeast $(n=13$; $37.1 \%)$ and South $(n=17 ; 48.6 \%)$. The sample included nurses $(n=22 ; 62.8 \%)$, nursing technicians or assistants $(n=8 ; 22.8 \%)$, dentists $(n=2 ; 5.7 \%)$, a physician $(n=1 ; 2.9 \%)$, a physical therapist $(n=1 ; 2.9 \%)$ and a speech therapist $(n=1 ; 2.9 \%)$. The prevalent type of health institution was the hospital $(n=28$; $80.0 \%)$; however, there were participants who worked in emergency care unit, long-stay institution for older adults, field hospital, basic health unit, outpatient clinic and home care.

Each participant answered the final version of the adapted questionnaire in order to assess understanding and clarity of the items ${ }^{12}$. The questionnaire called 'Assessment of Instruments' Feasibility" was used in order to assess the participants' ease to understand the questions, answer the instrument and determine the mean time to complete $i^{17}$. Once the pre-test was finished, the final version in Portuguese was obtained.

The participants of all the stages (translators, evaluators and pre-test) were invited to participate in the study by electronic means (e-mail or messenger application). Initially, the objectives and techniques of data collection were presented to the potential participants, along with a link to access the electronic form.

The first part of the electronic form presented the Free and Informed Consent Form (FICF), and consent to voluntarily participate in the study was given by selecting the option "I agree to participate". 
After consent, the participants were requested to fill in the electronic form made available for access by means of the Google Forms platform for the translators and evaluators, and through the kobotoolbox platform in the pre-test.

The translation and back-translation stages were developed between June $23^{\text {rd }}$ and July $26^{\text {th }}$, 2020 , and the equivalence evaluations by the experts committee was carried out between July $29^{\text {th }}$ and August $25^{\text {th }}, 2020$, in two evaluation rounds. Finally, the pre-test data collection period was from August $26^{\text {th }}$ to September $20^{\text {th }}, 2020$.

The data were stored in the servers' cloud and made available in the Excel for Windows spreadsheet format. Subsequently, they were made compatible in the Statistical Package for the Social Sciences (SPSS) database, version 22, for treatment purposes.

To describe the profiles of the experts committee members and of the participants in the pre-test, frequency and percentage of the categorical variables and position measures (mean and standard deviation) of the continuous variables were evaluated. The reliability of the instrument's total items related to activities developed by the health professional with patients with COVID-19 and adherence to the infection control procedures during care interactions and during aerosol-generating procedures was evaluated by means of Cronbach's alpha coefficient. These questions are used to assess exposure risk and to classify the risk.

This research is part of the study entitled "Assessment of the health professionals' exposure risk and of the availability of Personal Protective Equipment in the context of COVID-19" approved by the Committee of Ethics in Research with Human Beings of Universidade Federal de Juiz de Fora. All the participants expressed their consent by signing an electronic form, which contained the Free and Informed Consent Form (FICF).

\section{RESULTS}

The synthesis version submitted to evaluation by the experts committee presented a CVI value over 0.90 for most of the items. Despite that, the suggestions presented by the evaluators, such as the proposal to improve the wording of the items, were assessed and accepted. The items that obtained CVI values below 0.90 were forwarded to a second evaluation round and, in this stage, consensus was established among the evaluators. The questions that obtained CVI values below 0.90 are presented in Chart 1 .

Chart 1 - Items of the original and synthesis versions, CVI and final version after evaluation by the experts committee. Juiz de Fora, MG, Brazil, 2020.

\begin{tabular}{|l|c|c|c|c|}
\hline Original & $\begin{array}{c}\text { Synthesis of } \\
\text { the translations }\end{array}$ & $\mathbf{C V I}^{*}$ & $\begin{array}{c}\text { Final version after } \\
\text { experts committee }\end{array}$ & CVI† \\
\hline $\begin{array}{l}\text { Type of health } \\
\text { care personnel }\end{array}$ & Tipo de pessoal de saúde & 0.72 & Categoria profissional & 1.0 \\
\hline $\begin{array}{l}\text { Health worker } \\
\text { interactions } \\
\text { with COVID-19 } \\
\text { patient information }\end{array}$ & $\begin{array}{c}\text { Informações sobre } \\
\text { interações do (a) profissional } \\
\text { de saúde com o paciente } \\
\text { com COVID-19 }\end{array}$ & 0.86 & $\begin{array}{c}\text { Informações sobre o contato } \\
\text { do profissional de saúde com } \\
\text { o paciente com COVID-19 }\end{array}$ & 1.0 \\
\hline $\begin{array}{l}\text { Type of health } \\
\text { care setting }\end{array}$ & $\begin{array}{c}\text { Tipo de estabelecimento } \\
\text { de saúde }\end{array}$ & 0.86 & Tipo de instituição de saúde & 1.0 \\
\hline $\begin{array}{l}\text { Open airway } \\
\text { suctioning }\end{array}$ & Aspiração aberta de via aérea & 0.83 & $\begin{array}{c}\text { Aspiração de vias aéreas } \\
\text { por sistema aberto }\end{array}$ & 1.0 \\
\hline
\end{tabular}

${ }^{*} \mathrm{CVI}=$ Content Validity Index in the first evaluation round. $\dagger \mathrm{CVI}=$ Content Validity Index in the second evaluation round. 
Other situations presented by the evaluators in the first round were also forwarded for a new evaluation, namely: a) write in full the terms "profissional de saúde" ("health professional") and "prevenção e controle de infecção" ("infection prevention and control") as it is not common to use acronyms for these terms in the Brazilian context; b) invert the order of the "surname" and "first name" variables since, in Brazil, the name is presented before the surname in everyday life; c) include the "State" variable, since the original instrument only presents the "City" and "Country" options. Brazil is a large country and is geographically organized in 26 states and the Federal District; d) remove the "médico assistente" (original = Physician assistant); "flebotomista" (original = Phlebotomist); and "fisioterapeuta respiratório" (original = Respiratory therapist) professional categories. The first two professions were removed for not being part of the Brazilian context, and the last, for being a physiotherapy specialty in Brazil; e) include a space for the specialty of physicians, as the only specialty that appears in the original version is "ophthalmologist".

Another point discussed was the change in the wording of the original version regarding the instruction to fill in the frequency of use of the PPE. The description presented in the instrument for the "Na maioria das vezes" option overrides "Sempre, conforme recomendado", as it includes the range above $95 \%$ ('Always, as recommended' means more than $95 \%$ of the time; 'Most of the time' means $50 \%$ or more but not $100 \%$ ). Based on this observation made by one of the evaluators, the text of this guideline was redefined as: "Sempre, conforme recomendado" significa mais de 95\% das vezes; "Na maioria das vezes" significa de $50 \%$ ou mais até menos de 95\% ("Always, as recommended" means more than $95 \%$ of the time; "Most of the time" means $50 \%$ or more up to less than $95 \%$ ).

As for the question that assesses the protocols for the use of PPE in aerosol-generating procedures, the original version of the instrument exemplifies the PPE including surgical mask. In this sense, one of the evaluators questioned the pertinence of the item, as the national protocols recommend the use of $\mathrm{N95}$ masks or equivalent models in these cases. Therefore, for this item, it was decided to substitute the term "máscara cirúrgica" ("surgical mask") for "máscara N95 ou equivalente" (N95 mask or equivalent").

In the pre-test stage, the instrument was positively evaluated by most of the participants. In relation to the questionnaire instructions, $80.0 \%$ and $77.1 \%$ of the participants fully agreed that the instrument's instructions and questions were easy to understand, respectively. In addition to that, $91.4 \%$ fully agreed that it was easy to mark the answers in the questionnaire (Table 1).

Table 1 - Assessment of the applicability of the instrument translated and adapted to Portuguese. Juiz de Fora, MG, Brazil, 2020. $(n=35)$

\begin{tabular}{lccccc}
\hline Item $^{* *}$ & $\begin{array}{c}\text { TA* } \\
\mathbf{n}(\%)\end{array}$ & $\begin{array}{c}\text { PA† } \\
\mathbf{n}(\%)\end{array}$ & $\begin{array}{c}\text { RNSł } \\
\mathbf{n}(\%)\end{array}$ & $\begin{array}{c}\text { PD§ } \\
\mathbf{n}(\%)\end{array}$ & $\begin{array}{c}\text { TD|| } \\
\mathbf{n}(\%)\end{array}$ \\
\hline Understanding of the instructions & $28(80.0)$ & $6(17.1)$ & - & - & $1(2.9)$ \\
Understanding of the questions & $27(77.1)$ & $8(22.9)$ & - & - & - \\
Ease to mark the answers & $32(91.4)$ & $3(8.6)$ & - & - & - \\
\hline
\end{tabular}

${ }^{*} \mathrm{TA}=$ Totally Agree; $† \mathrm{PA}=$ Partially Agree; $\ddagger R N S=$ Rather Not Say; $\S P D=P a r t i a l l y ~ D i s a g r e e ; ~ \| T D=$ Totally Disagree.

${ }^{* *}$ Answers to the "Assessment of Instruments' Feasibility" questionnaire ${ }^{17}$.

The final version of the instrument called "Avaliação do risco e manejo da exposição de profissionais de saúde no contexto da COVID-19 - versão brasileira" is attached. The instrument's reliability was confirmed by means of the Cronbach's alpha coefficient (0.76). 


\section{DISCUSSION}

By translating and validating the "Risk assessment and management of exposure of health care workers in the context of COVID-19: Interim guidance" instrument, it was possible to present a version in Brazilian Portuguese. By following the recommended stages of the validation process ${ }^{12}$, it is ensured that the translated and adapted version will be able to investigate the working conditions of the health professionals who are active in the pandemic context.

The independent translation by two translators enables simultaneous conceptual and literary translation ${ }^{18}$. The synthesis stage aligned the translations and consolidated the version that would be forwarded to the back-translation stage ${ }^{18}$. For the synthesis of these translated versions, the agreement of the researchers who evaluated the translated versions with the research objectives and with the Brazilian cultural context was adopted. The independent evaluation by the experts committee valued the effective freedom of the members to analyze the questions ${ }^{19-20}$. In addition to that, they were able to consider their own reflections, experiences and knowledge regarding the country's health conditions in the pandemic context, as this stage was carried out during the events of COVID-19 progression in Brazil.

The evaluators contribute to the quality of the translation by incorporating in their assessment academic expertise in relation to the theme assessed in the questionnaire ${ }^{19-20}$. The analysis performed in each question was based on an attempt to achieve coherence between precise language and the cultural context, so that the participant would not have any difficulty understanding and would feel encouraged to participate ${ }^{20}$.

The factors related to the wording of the questions scored by the evaluators brought about greater clarity and favored comprehensibility. This was necessary because the instrument is intended for workers with different training levels. Thus, it is necessary to use of clear, objective, zealous and easy-to-understand language in the wording of the questions. Confirming that the changes were positive, a favorable assessment was obtained regarding the instrument's feasibility ${ }^{17}$, and, among the pre-test participants, most of them answered that they understood the instructions and questions and that it was easy to mark the answers.

Due to their activity, health professional are at a high risk of infection, and understanding this risk is essential to develop preventive measures that can protect them and provide prevention against the COVID-19 infection and other infectious diseases ${ }^{11}$. In this context, the use of this questionnaire is intended to offer another instrument that can serve as a contribution to the survey of these professionals' exposure to contamination in their workplaces.

Studying the health professionals' real working conditions is the most effective way to conduct future interventions in order to provide safety in an equitable manner. It is emphasized that the measures to control infection by SARS-CoV-2 or other infectious agents emphasize the importance of the actions to prevent infection risk among workers at different care levels, with the use of PPE and the importance of hand hygiene standing out ${ }^{21}$.

Individual prevention measures are indispensable to protect these workers, through the adequate offer of PPE that meets the biosafety needs, thus favoring a safe work environment ${ }^{22}$. In this context, the traditional protection measures needed to be rethought in order to address the pandemic ${ }^{23}$, with permanent repercussions on the care practice. The analysis of the availability of PPE elements and their use makes it possible to know the safety conditions of the work environment and allows targeting the necessary adaptations during health care.

The survey of the risk factors for contamination has shown that scarcity of PPE, combined with overload in the work environment, contributes to the maintenance of behaviors characterized by reduced attention in the workers, as well as to non-compliance with good biosafety habits ${ }^{24}$. Interventions that 
seek to prevent health professionals' contamination are factors intended to control spread of disease to their contacts, whether by means of community contamination or in relation to the work activity ${ }^{23}$.

Some aspects have been emphasized at this time of a major public health emergency worldwide: unhealthy working conditions, characterized by scarcity of materials; shortage of professionals and low compliance with the biosafety recommendations and patient safety protocols ${ }^{25}$. From the Brazilian perspective, it is necessary to mobilize the managers and administrators of health institutions so that they can strengthen the aspects that present gaps in the protection of the group of health workers and jointly discuss the situations to be faced ${ }^{23}$. Investigating the risks of professional exposure to contamination and accidents with biological materials makes it possible to intervene in these conditions and monitor them.

Thus, the version of the instrument that was translated and adapted to the Brazilian context contributes both to the workers' health and to the health institutions, enabling knowledge of aspects related to professional safety. Its use may generate relevant information for health workers and managers, allowing to establish action plans for professional safety. In turn, in the scope of safety, it may enable greater professional satisfaction and lower absenteeism rates, aspects that can contribute for early recovery and better use of the beds available in the health care spaces.

\section{CONCLUSION}

The instrument entitled "Risk assessment and management of exposure of health care workers in the context of COVID-19" was translated and adapted for Brazil, following the necessary methodological recommendations. In this sense, an instrument validated by an experts committee is presented, which showed good applicability. The importance of using this instrument lies in the fact that it is a proposal developed by the WHO, which allows international comparison of the results, as well as using the data obtained for assessment and decision-making in relation to workers' health.

As a limitation of this research we must mention the need to assess the psychometric properties of the instrument presented, as well as to employ it in larger samples in order to validate its applicability among different health care workers since, in this study, the pre-test was only applied to a small sample.

It is suggested that research studies be conducted using this instrument in different care settings, in addition to sharing the information with the $\mathrm{WHO}$ in order to contribute to the construction of global knowledge about the risks to which health professionals are exposed.

\section{REFERENCES}

1. Shereen MA, Khan S, Kazmi A, Bashir N, Siddique R. COVID-19 infection: origin, transmission, and characteristics of human coronaviruses. J Adv Res [Internet]. 2020 [cited 2020 Dec 16];24(4):918. Available from: http://doi.org/10.1016/j.jare.2020.03.005

2. Wang L, Wang Y, Ye D, Liu Q. Review of the 2019 novel coronavirus (SARS-CoV-2) based on current evidence. Int J Antimicrob Agents [Internet]. 2020 [cited 2020 Dec 22];55(6):105948. Available from: http://doi.org/10.1016/j.jjantimicag.2020.105948

3. World Health Organization. WHO Coronavirus Disease (COVID-19) Dashboard [Internet]. Geneva (CH): WHO; 2021 [cited 2021 Feb 23]. Available from: https://covid19.who.int

4. Ministério da Saúde. Painel Coronavírus [Internet]. Brasília, DF(BR): MS; 2021 [cited 2021 Feb 23]. Available from: https://covid.saude.gov.br/

5. Bai Y, Yao L, Wei T, Tian F, Jin DY, Chen L, et al. Presumed asymptomatic carrier transmission of COVID-19. JAMA [Internet] 2020 [cited 2020 Dec 16];323(14):1406-7. Available from: http:// doi.org/10.1001/jama.2020.2565 
6. Agência Nacional de Vigilância Sanitária (BR). Nota Técnica GVIMS/GGTES/ANVISA N 04/2020: orientações para serviços de saúde: medidas de prevenção e controle que devem ser adotadas durante a assistência aos casos suspeitos ou confirmados de infecção pelo novo coronavírus (SARS-CoV-2) [Internet]. Brasília, DF(BR): ANVISA; 2020 [cited 2020 Dec 18]. Available from: https://www20.anvisa.gov.br/segurancadopaciente/index.php/alertas/item/nota-tecnica-n-042020-gvims-ggtes-anvisa-atualizada

7. Ministério da Saúde. Diretrizes para diagnóstico e tratamento da Covid-19 [Internet]. Brasília, DF(BR): MS; 2020 [cited 2020 Dec 28]. Available from: https://portalarquivos.saude.gov.br/ images/pdf/2020/May/08/Diretriz-Covid19-v4-07-05.20h05m.pdf

8. Sookaromdee P, Wiwanitkit V. Imported cases of 2019-novel coronavirus (2019-nCoV) infections in Thailand: Mathematical modelling of the outbreak. Asian Pac J Trop Med [Internet]. 2020 [cited 2020 Dec 16];13(3):139-40. Available from: http://doi.org/10.4103/1995-7645.277516

9. Oliveira AC, Lucas TC, Iquiapaza RA. O que a pandemia da covid-19 tem nos ensinado sobre adoção de medidas de precaução? Texto Contexto Enferm [Internet]. 2020 [cited 2021 Feb 22];29:e20200106. Available from: https://doi.org/10.1590/1980-265x-tce-2020-0106

10. World Health Organization. COVID-19: Occupational health and safety for health workers: interim guidance [Internet]. Geneva (CH): WHO; 2021 [cited 2021 Feb 13]. Available from: https://www. who.int/publications/i/item/WHO-2019-nCoV-HCW_advice-2021.1

11. World Health Organization. Risk assessment and management of exposure of health care workers in the context of COVID-19: interim guidance,19 March 2020 [Internet]. Geneva (CH): WHO; 2020 [cited 2020 Jun 13]. Available from: https://apps.who.int/iris/handle/10665/331496

12. Beaton D, Bombardier C, Guillemin F, Ferraz M. Recommendations for the Cross-Cultural Adaptation of the DASH \& QuickDASH Outcome Measures. Am Acad Orthop Surg [Internet]. 2007 [cited 2020 Dec 16];3-13. Available from: https://www.dash.iwh.on.ca/sites/dash/files/ downloads/cross_cultural_adaptation_2007.pdf

13. Souza AC, Alexandre NMC, Guirardello EB. Psychometric properties in instruments evaluation of reliability and validity. Epidemiol Serv Saude. [Internet]. 2017 [cited 2020 Dec 28];26(3):64959. Available from: https://doi.org/10.5123/S1679-49742017000300022

14. Coluci $\mathrm{MZO}$, Alexandre NMC, Milani D. Construção de instrumentos de medida na área da saúde. Cien Saúde Colet [Internet]. 2015 [cited 2020 Dec 28];20(3):925-36. Available from: https://doi. org/10.1590/1413-81232015203.04332013

15. Alexandre NMC, Gallasch $\mathrm{CH}$, Lima MHM, Rodrigues RCM. A confiabilidade no desenvolvimento e avaliação de instrumentos de medida na área da saúde. Rev Eletrônica Enferm [Internet]. 2013 [cited 2020 Dec 28];15(3):802-9. Available from: https://doi.org/10.5216/ree.v15i3.20776

16. Alexandre NMC, Coluci MZO. Content validity in the development and adaptation processes of measurement instruments. Cien Saúde Colet [Internet]. 2011 [cited 2020 Dec 28];16(7):3061-8. Available from: https://doi.org/10.1590/S1413-81232011000800006.

17. Coluci MZO, Alexandre NMC. Development of a questionnaire to evaluate the usability of assessment instruments. Rev Enferm UERJ. 2009;17(3):378-82.

18. Epstein J, Santo RM, Guillemin F. A review of guidelines for cross-cultural adaptation of questionnaires could not bring out a consensus. J Clin Epidemiol [Internet] 2015 [cited $2021 \mathrm{Jan}$ 17];68(4):435-41. Available from: https://doi.org/10.1016/j.jclinepi.2014.11.021

19. Epstein J, Osborne RH, Elsworth GR, Beaton DE, Guillemin F. Cross-cultural adaptation of the Health Education Impact Questionnaire: experimental study showed expert committee, not back-translation, added value. J Clin Epidemiol [Internet]. 2015 [cited 2021 Jan 17];68(4):360-9. Available from: http://doi.org/10.1016/j.jclinepi.2013.07.013 
20. Nora CRD, Zoboli E, Vieira MM. Validation by experts: importance in translation and adaptation of instruments. Rev Gaúcha Enferm [Internet]. 2017 [cited 2021 Feb 22];38(3):e64851. Available from: https://doi.org/10.1590/1983-1447.2017.03.64851

21. Teixeira CFS, Soares CM, Souza EA, Lisboa ES, Pinto ICM, Andrade LR, et al. The health of healthcare professionals coping with the covid-19 pandemic. Cien Saúde Colet [Internet]. 2020 [cited 2020 Feb 16];25(9):3465-74. Available from: https://doi.org/10.1590/1413-81232020259.19562020

22. Helioterio MC, Lopes FQRS, Sousa CC, Souza FO, Pinho PS, Sousa FNF, Araújo TM. Covid-19: Por que a proteção de trabalhadores e trabalhadoras da saúde é prioritária no combate à pandemia? Trab Educ Saúde [Internet]. 2020 [cited 2020 Dec 16];18(3):e00289121. Available from: https://doi.org/10.1590/1981-7746-sol00289

23. Silva LS, Machado EL, Oliveira HN, Ribeiro AP. Condições de trabalho e falta de informações sobre o impacto da COVID-19 entre trabalhadores da saúde. Rev Bras Saúde Ocup [Internet] 2020 [cited 2021 Feb 05];45(24):e24. Available from: https://doi.org/10.1590/2317-6369000014520

24. Sant'Ana G, Imoto AM, Amorim FF, Taminato M, Peccin MS, Santana LA, Göttems LBD, Camargo EB. Infection and death in healthcare workers due to COVID-19: a systematic review. Acta Paul Enferm [Internet]. 2020 [cited 2020 Feb 12];33:eAPE20200107. Available from: https://doi. org/10.37689/acta-ape/2020ao0107

25. Ehrlich $\mathrm{H}$, McKenney M, Elkbuli A. Protecting our healthcare workers during the COVID-19 pandemic. Am J Emerg Med [Internet]. 2020 [cited 2021 Feb 20];38(7):1527-8. Available from: https://doi.org/10.1016/j.ajem.2020.04.024 


\section{NOTES}

\section{ORIGIN OF THE ARTICLE}

Extracted from the research - Assessment of the health professionals' exposure risk and of the availability of Personal Protective Equipment in the COVID-19 context, developed at the Graduate Program in Nursing of Universidade Federal de Juiz de Fora, in 2021.

\section{CONTRIBUTION OF AUTHORITY}

Study design: Dutra HS, Thofehrn MB, Dutra LS.

Data collection: Dutra HS, Thofehrn MB, Dutra LS.

Data analysis and interpretation: Dutra HS, Dutra LS.

Discussion of the results: Dutra HS, Araújo CR, Braga LM, Carbogim FC, Coelho ACO.

Writing and/or critical review of the content: Dutra HS, Araújo CR, Dutra LS, Braga LM, Carbogim FC, Coelho ACO.

Review and final approval of the final version: Dutra HS, Dutra LS, Thofehrn MB, Araújo CR, Braga LM, Carbogim FC, Coelho ACO.

\section{FUNDING INFORMATION}

One of the members of this research (ARAÚJO CR) received a master's scholarship from Universidade Federal de Juiz de Fora - Process No. 23071.901556/2021-64.

\section{APPROVAL OF ETHICS COMMITTEE IN RESEARCH}

Approved in the Research Ethics Committee of Universidade Federal de Juiz de Fora, opinion No.4,031,046/2020 and Certificate of Presentation for Ethical Appreciation No. 30933120.5.0000.5147.

\section{CONFLICT OF INTEREST}

There is no conflict of interest.

\section{EDITORS}

Associated Editors: Gisele Cristina Manfrini, Natália Gonçalves, Ana Izabel Jatobá de Souza. Editor-in-chief: Roberta Costa.

\section{HISTORICAL}

Received: March 03, 2021.

Approved: August 24, 2021.

\section{CORRESPONDING AUTHOR}

Herica Silva Dutra

herica.dutra@ufjf.br

\section{SUPPLEMENTARY MATERIAL}

The following online material is available for this article:

Avaliação do risco e manejo da exposição de profissionais de saúde no contexto da COVID-19 versão brasileira 